\title{
Pengaruh Kadar Ampas Tahu Pada Pakan Ikan Gabus Channa gachua Terhadap Kadar Albumin Daging
}

\author{
JEFRI PERMADI $^{1}$, DHUTA SUKMARANI ${ }^{3}$, MUDIYONO $^{2}$ \\ ${ }^{1}$ Program Studi D3 Budidaya Perikanan, Politeknik Muhammadiyah Magelang \\ Jl. Tentara Pelajar No. 12, Muntilan, Magelang, Jawa Tengah. 56413 \\ email: jefri.pmm@gmail.com \\ ${ }^{2}$ Program Studi D3 Teknik Lingkungan, Politeknik Muhammadiyah Magelang \\ Jl. Tentara Pelajar No. 12, Muntilan, Magelang, Jawa Tengah. 56413 \\ email: mudiyono.pmm@gmail.com \\ ${ }^{3}$ Program Studi PGSD Fakultas Keguruan dan Ilmu Pendidikan, \\ Universitas Muhammadiyah Magelang, \\ Jl. Mayjend Bambang Soegeng Sumberrejo Mertoyudan, Magelang, Jawa Tengah. 56172 \\ email: dhutasukmarani@ummgl.ac.id
}

\begin{abstract}
The need for medical albumin is currently at $91 \%$, which is relatively expensive price of albumin causes many people to switch to a cheap source of albumin of snakehead fish. This led to the exploitation of snakehead fish on a large scale so that the fish populations in natural will experience deterioration. Until now, the snakehead fish has not been cultivated by farmers because the fish is not a commodity featured and high production costs of the feed sector. Meanwhile, the potential for additional material feed nutrients are available quite easily and cheaply from the waste tofu. Utilization of bagasse as a mixture of snakehead fish feed can be an alternative to reduce the cost of the feed without reducing the quality of fish in terms of content snakehead fish albumin. In addition, tofu is used as dietary supplement of snakehead fish is expected to reduce the rate of environmental pollution caused by waste agricultural products. The method was used in this research is experimental. Snakehead fish is reared for 17 days with one control and four treatments of feed that is, commercial feed with a mixture of $20 \%, 40 \%, 50 \%$ and $70 \%$ tofu waste. After 17 days of snakehead fish from each treatment were analyzed its albumin levels. The data analysis using regression and correlation to determine the relationship between the treatments of feed against the observed variables. Results of regression and correlation analysis shows that administration of tofu waste in different concentrations has no effect on the feed exhibited significantly to weight and body length of the fish, the oxygen content, $\mathrm{pH}$, water temperature, weight of the test sample and albumin levels in fish flesh. But the determinant of constant value shows that there is one variable that have relevance to the treatment. Based on Pearson correlation test, it is known that high levels of tofu waste given to the feed associated with increased levels of albumin catfish at each treatment. The highest levels of snakehead fish albumin is $4,835 \mathrm{~g} / 100 \mathrm{~g}$ of fish meat on the treatment of $70 \%$ tofu waste out on feed, while the lowest levels of albumin is contained in the 2286 control treatment that is $0 \%$ tofu waste to the snakehead feed.
\end{abstract}

Keywords: albumin, dietary, snakehead fish, tofu waste

\section{INTISARI}

Kebutuhan albumin untuk medis saat ini mencapai 91\%, harga albumin yang relatif mahal menyebabkan masyarakat banyak beralih ke sumber albumin yang murah yaitu ikan Gabus. Hal tersebut menyebabkan eksploitasi ikan Gabus secara besar-besaran sehingga populasi ikan gabus di alam akan mengalami penurunan. Sampai saat ini, ikan gabus belum banyak dibudidayakan oleh petani ikan karena bukan merupakan komoditas unggulan dan biaya produksi yang tinggi dari sektor pakan. Sementara itu, potensi bahan tambahan nutrisi pakan tersedia cukup mudah dan 
murah dari limbah ampas tahu. pemanfaatan ampas sebagai bahan campuran pakan ikan gabus dapat menjadi alternatif untuk menekan biaya pakan tanpa harus mengurangi kualitas ikan gabus dalam hal kandungan albuminnya. Selain itu, ampas tahu yang dimanfaatkan sebagai campuran pakan ikan gabus diharapkan dapat mengurangi laju polusi lingkungan akibat limbah hasil pertanian. Metode yang digunakan dalam penelitian ini yaitu penelitian eksperimental. Ikan gabus dipelihara selama 17 hari dengan 1 kontrol dan empat perlakuan pakan yaitu, pakan komersial dengan campuran 20\%, 40\%, 50\% dan 70\% ampas tahu. Setelah 17 hari ikan gabus dari masingmasing perlakuan dianalisis kandungan albuminnya. Analisis data menggunakan metode regresi dan korelasi untuk mengetahui hubungan antara perlakuan pakan terhadap variabel yang diamati. Hasil analisis regresi dan korelasi menunjukkan bahwa pemberian ampas tahu dalam konsentrasi berbeda pada pelet tidak berpengaruh signifikan terhadap berat dan panjang tubuh ikan, kadar oksigen, $\mathrm{pH}$, suhu air, berat sampel uji dan kadar albumin dalam daging ikan. Namun dari nilai konstanta determinan menunjukkan bahwa terdapat salah satu variabel yang memiliki keterkaitan dengan perlakuan. Berdasarkan uji korelasi Pearson, diketahui bahwa kadar ampas tahu yang diberikan pada pakan berkaitan dengan kenaikan kadar albumin ikan gabus pada masing-masing perlakuan. Kadar albumin ikan gabus tertinggi adalah $4.835 \mathrm{~g} / 100 \mathrm{~g}$ daging ikan pada perlakuan $70 \%$ ampas tahu pada pelet, sedangkan kadar albumin terendah adalah 2.286 terdapat pada perlakuan control yaitu $0 \%$ ampas tahu pada pelet ikan gabus.

Kata Kunci: albumin, ampas tahu, gabus, pelet

\section{PENDAHULUAN}

Ikan gabus Channa sp. diketahui mengandung $60 \%$ senyawa albumin, dalam $100 \mathrm{~g}$ daging ikan gabus mengandung $6,224 \mathrm{~g}$ albumin (Isnawati et al., 2015; Harianti, 2013), kandungan albumin pada ikan gabus diketahui lebih tinggi dibanding sumber albumin lainnya, sehingga menjadi andalan bagi dunia medis untuk memenuhi kebutuhan albumin. Harga serum albumin sampai saat berkisar Rp. 850.000 per $100 \mathrm{ml}$ dan sangat berbeda dengan harga albumin yang dikemas dalam bentuk kapsul dari ikan gabus yaitu $\mathrm{Rp}$. 120.000 per 30 kapsul. Harga albumin ikan gabus yang lebih murah tersebut menjadi alternatif untuk memenuhi kebutuhan albumin dalam jumlah banyak. Sayangnya, ikan gabus yang banyak dimanfaatkan albuminnya tersebut masih mengandalkan hasil tangkapan di alam, dalam jangka panjang eksploitasi ikan gabus dari alam berpotensi menurunkan populasinya.

Budidaya ikan gabus adalah salah satu upaya untuk menekan penurunan populasi akibat eksploitasi ikan gabus di alam. Penelitian mengenai upaya domestikasi ikan gabus untuk dibudidayakan telah dilakukan oleh Astria et al. (2013) menunjukkan bahwa larva ikan gabus dapat hidup dengan baik

pada air dengan $\mathrm{pH} 5$ dengan nilai survival rate dan biomassa masing-masing adalah $67.90 \%$ dan $9.8982 \mathrm{~g}$. Modifikasi rasio kadar lipid dan protein pada pakan dengan rasio kadar protein 65/450 g dapat memberikan performa pertumbuhan dan tingkat ketahanan hidup larva ikan gabus yang baik (PaikoAliyu et al., 2010). Penelitian mengenai perbedaan pemberian kadar protein pakan ikan gabus terhadap pertumbuhan dan kandungan albumin pada ikan gabus sebenarnya telah dilakukan oleh Kusumaningrum et al. (2014) dengan memanipulasi kadar protein pada pelet ikan komersial pada masing-masing perlakuan dan hasilnya adalah pakan komersial yang mengandung protein $32 \%$ dapat mempercepat pertumbuhan dan meningkatkan kandungan albumin pada tubuh ikan gabus.

Pelet komersial mengandung nutrisi yang lengkap. Namun, harga pelet ikan komersial termasuk mahal bagi ikan yang belum menjadi komoditas utama seperti ikan gabus. Penggunaan limbah ampas tahu sebagai campuran pakan ikan gabus diharapkan dapat menekan biaya produksi di sector pakan tanpa mengurangi kualitas nutrisi pakan tersebut. Limbah hasil produksi tahu mengandung mengandung bahan organik berupa protein 
(9\%), lemak $(0,69 \%)$, karbohidrat $(0,105 \%)$ dan $1,5 \%$ nitrogen terlarut.

Pemanfaatan limbah ampas tahu sebagai bahan pakan dalam budidaya perikanan belum banyak dilaporkan. Melalui penelitian ini, potensi limbah ampas tahu dalam budidaya perikanan dapat diketahui dengan memanfaatkannya sebagai bahan campuran pakan ikan gabus untuk menghasilkan albumin yang cukup serta mengetahui pengaruhnya terhadap kualitas air media budidaya.

\section{METODE}

Metode yang digunakan dalam penelitian ini mengacu pada penelitian yang telah dilakukan oleh Kusumaningrum et al. (2014) yaitu eksperimental dengan lima perlakuan dan tiga kali ulangan.

Perlakuan yang diberikan yaitu dengan menambahkan ampas tahu pada pelet ikan dalam konsentrasi yang berbeda. Perbandingan kadar ampas tahu yang dicampur ke dalam pakan ikan gabus dihitung berdasarkan proporsi kadar pelet komersial diluar kadar tepung ikan (sebagai atraktan) sebanyak 20\% dan tepung kanji (sebagai perekat) $10 \%$. Pada perlakuan pertama P1 ampas tahu $20 \%$ diberikan ke ikan gabus, Perlakuan kedua P2 pelet dicampur dengan $40 \%$ ampas tahu, perlakuan ke tiga $\mathrm{P} 3$ pelet dicampur 50\% ampas tahu, perlakuan keempat $\mathrm{P} 4$ pelet dicampur $70 \%$ ampas tahu, dan pelet tanpa campuran ampas tahu P0 dijadikan sebagai kontrol perlakuan. Parameter utama yang diamati dalam penelitian ini adalah kadar albumin dan laju pertumbuhan ikan gabus. Parameter penunjang berupa kualitas air diantaranya adalah $\mathrm{pH}$, kadar oksigen terlarut dan suhu air pemeliharaan ikan gabus.

Data kandungan albumin ikan gabus dari masing-masing perlakuan dan data kualitas air akuarium dan dianalisis menggunakan metode regresi-korelasi. Analisis ini digunakan untuk mengetahui jenis variabel yang berhubungan terhadap perlakuan yaitu kadar ampas tahu yang berbeda pada pelet.

\section{HASIL}

Tabel 1. Hasil pengukuran kadar albumin (KA), berat sampel uji (BSU) dan kadar ampas tahu pada pelet ikan Gabus.

\begin{tabular}{ccccc}
\hline No. & Kode Sampel & $\begin{array}{c}\text { K A } \\
\text { (per g/100 }\end{array}$ & BSU & Keterangan \\
\hline $\mathbf{1}$ & P0U1 & 2.302 & 2.072 & $0 \%$ AT \\
\hline $\mathbf{2}$ & P1U1 & 2.851 & 2.011 & $20 \%$ AT \\
\hline $\mathbf{3 .}$ & P2U1 & 3.401 & 2.206 & $40 \%$ AT \\
\hline $\mathbf{4 .}$ & P3U1 & 4.134 & 2.040 & $50 \%$ AT \\
\hline $\mathbf{5 .}$ & P4U1 & 4.670 & 2.053 & $70 \%$ AT \\
\hline $\mathbf{6 .}$ & P0U2 & 2.286 & 2.025 & $0 \%$ AT \\
\hline $\mathbf{7 .}$ & P1U2 & 2.902 & 2.008 & $40 \%$ AT \\
\hline $\mathbf{8 .}$ & P2U2 & 3.608 & 2.029 & $50 \%$ AT \\
\hline $\mathbf{9 .}$ & P3U2 & 4.227 & 2.016 & $70 \%$ AT \\
\hline $\mathbf{1 0 .}$ & P4U2 & 4.835 & 2.010 & $0 \%$ AT \\
\hline $\mathbf{1 1 .}$ & P0U3 & 2.335 & 2.025 & $40 \%$ AT \\
\hline $\mathbf{1 2 .}$ & P1U3 & 2.870 & 2.030 & $50 \%$ AT \\
\hline $\mathbf{1 3 .}$ & P2U3 & 3.524 & 2.018 & $70 \%$ AT \\
\hline $\mathbf{1 4 .}$ & P3U3 & 4.185 & 2.005 & Dari Alam \\
\hline $\mathbf{1 5 .}$ & P4U3 & 4.748 & 2.022 & 2.005 \\
\hline $\mathbf{1 6 .}$ & P4U4* & 4.599 & & \\
\hline
\end{tabular}

Keterangan: $\mathrm{AT}=$ Ampas Tahu

Berdasarkan nilai kadar albumin ikan gabus terhadap kada ampas tahu pelet mengindikasikan adanya korelasi antara keduanya. Kadar albumin ikan gabus bertambah bersama dengan bertambahnya kadar ampas tahu pelet ikan, dan tidak terlihat 
adanya hubungan antara bertambahnya kadar albumin ikan dengan berat sampel uji.

Berat ikan yang digunakan selama penelitian tidak seragam dan kurang menggambarkan hubungan antara bobot dan panjang tubuh, terhadap kadar albumin daging ikan gabus.

Hubungan antara kadar albumin ikan terhadap variabel yang diamati akan disajikan pada tabel 2 berikut:

Tabel 2. Korelasi Pearson antar variabel penelitian yang diamati

\begin{tabular}{cccccccccc}
\hline & & KAT & KA & BSU & Pjg & Bb & Suhu & pH & O $_{2}$ \\
\hline & KAT & 1.000 & .989 & -.057 & .081 & -.226 & -.426 & -.161 & .000 \\
\cline { 2 - 10 } & $\mathrm{KA}$ & .989 & 1.000 & -.128 & .118 & -.207 & -.482 & -.123 & -.033 \\
\cline { 2 - 10 } & $\mathrm{BSU}$ & -.057 & -.128 & 1.000 & -.434 & -.319 & .198 & -.010 & .167 \\
\cline { 2 - 10 } Pearson & $\mathrm{Pjg}$ & .081 & .118 & -.434 & 1.000 & .862 & .125 & -.116 & -.412 \\
\cline { 2 - 10 } & $\mathrm{Bb}$ & -.226 & -.207 & -.319 & .862 & 1.000 & .324 & -.018 & -.405 \\
\cline { 2 - 10 } & $\mathrm{Suhu}$ & -.426 & -.482 & .198 & .125 & .324 & 1.000 & -.063 & .347 \\
\cline { 2 - 10 } & $\mathrm{pH}$ & -.161 & -.123 & -.010 & -.116 & -.018 & -.063 & 1.000 & -.328 \\
\hline & $\mathrm{O}_{2}$ & .000 & -.033 & .167 & -.412 & -.405 & .347 & -.328 & 1.000 \\
\hline
\end{tabular}

Keterangan: KAT (Kadar Ampas Tahu), KA (Kadar Albumin), BSU (Berat Sampel Uji), Pjg (Panjang tubuh ikan), Bb (Bobot Tubuh), Suhu Air, pH dan Kadar $\mathrm{O}_{2}$ terlarut

Hasil analisis korelasi antara kadar ampas tahu dengan beberapa variabel yang diamati dalam penelitian ini menunjukkan nilai variasi yang berbeda-beda. Dalam analisis korelasi Pearson, nilai antar dua variabel yang mendekati angka 1 dianggap memiliki keterkaitan. Tabel tersebut menunjukkan bahwa kadar ampas tahu yang diberikan pada masing-masing perlakuan lebih berpengaruh terhadap kenaikan kadar albumin dalam daging ikan disbanding panjang dan berat tubuh ikan, begitu juga dengan kualitas air $\mathrm{pH}$, suhu dan kadar $\mathrm{O}_{2}$ terlarut dalam air.

\section{PEMBAHASAN}

Albumin dalam daging ikan pada hakikatnya adalah sebuah poliribosom yang berikatan dengan organel reticulum endoplasma pada sel hati. Albumin disintesis dalam organ hati sebanyak 100-200 mikro gram per hari, sintesis albumin dipengaruhi oleh tiga faktor utama yaitu jenis asam amino yang masuk ke dalam tubuh melalui makanan yaitu triptofan, arginin, ornitin, lisin, fenilalanin, treonin dan prolin, kemudian pengaruh hormon diantaranya hormon pertumbuhan, insulin, adrenokortikotropik, testosteron dan korteks adrenal serta adanya suatu penyakit yang dapat menyebabkan gangguan sintesis albumin.
Peningkatan kadar albumin pada daging ikan gabus yang diukur dalam penelitian ini diduga bukan disebabkan oleh nutrisi dari pellet yang diberikan selama perlakuan. Alasan tersebut didasarkan pada data grafik hubungan antara bobot tubuh, berat sampel uji terhadap kadar albumin pada gambar 5.5 dan hasil analisis korelasi-regresi antar parameter yang diamati menunjukkan bahwa nilai korelasi antara bobot tubuh ikan dengan kadar albumin kurang dari 1 masing-masing yaitu 0.117 dan -0.127 untuk korelasi berat sampel uji dengan kadar albumin. Masing-masing parameter dinyatakan berkorelasi kuat jika mendekat 1. Sintesis albumin pada ikan gabus dalam penelitian ini diduga disebabkan oleh pengaruh hormon yang dipicu akibat perubahan kualitas media pemeliharaan yang disebabkan oleh pellet yang tidak termakan oleh ikan.

Parameter kualitas air yang paling berkorelasi terhadap kadar ampas tahu pada pelet dan kadar albumin ikan adalah kadar $\mathrm{O}_{2}$ terlarut dalam air dibanding dengan suhu air dan $\mathrm{pH}$ air. Nilai korelasi masing-masing parameter tersebut yaitu -0.211 dan -0.163 untuk suhu air terhadap kadar albumin dan kadar ampas tahu pada pellet, -0.123 dan 0.161 untuk $\mathrm{pH}$ air terhadap kadar albumin dan kadar ampas tahu pada pellet ikan serta 
masing-masing 0.339 untuk kadar $\mathrm{O}_{2}$ terlarut terhadap kadar albumin dan kadar ampas tahu pada pelet. Kualitas air pada media pemeliharaan diduga menjadi faktor perantara yang menyebabkan kadar albumin pada daging ikan gabus meningkat. Perubahan kualitas air media pemeliharaan ikan gabus dalam penelitian ini disebabkan oleh adanya pelet ikan gabus yang tidak termakan dan mengalami proses dekomposisi. Meskipun parameter kualitas air yang diamati pada penelitian ini sanat terbatas, namun dengan mengetahui korelasi nilai kadar $\mathrm{O}_{2}$ terlarut dalam air terhadap kadar albumin dan kandungan ampas tahu dalam pelet bisa digunakan sebagai pendekatan dalam mengestimasi faktor yang mempengaruhi bertambahnya kadar albumin pada daging ikan gabus.

Penelitian mengenai pengaruh faktor lingkungan terhadap profil albumin pada tubuh organisme pernah dilakukan oleh beberapa peneliti sebelumnya. Ikan gabus dari habitat berbeda memiliki profil asam amino yang berbeda pula, hal ini dipengaruhi oleh fungsi fisiologis asam amino sebagai pembawa protein dalam plasma tubuh (Susilowati et al., 2015). Pengaruh faktor lingkungan terhadap kadar albumin tubuh juga diketahui terjadi pada organisme lain selain ikan. Hasil penelitian Rahadian et al. (2015), Mushawwir dan Latipudin (2011) dan Marwadi et al. (2013) menunjukkan bahwa pengaruh suhu dan keberadaan senyawa $\mathrm{Pb}$ pada lingkungan dapat mempengaruhi kadar albumin dalam tubuh yang berubah karena pengaruh stres akibat perubahan kondisi lingkungan sekitarnya.

Pelet ikan yang telah dicampur ampas tahu dengan konsentrasi berbeda yang tidak termakan oleh ikan, tidak menyebabkan perubahan kualitas air yang signifikan, namun berpengaruh terhadap peningkatan kadar albumin pada daging ikan gabus meskipun hal tersebut tidak berhubungan secara signifikan terhadap berat dan panjang ikan gabus.

\section{KESIMPULAN}

Kadar albumin ikan gabus tertinggi yaitu $4.835 \mathrm{~g} / 100 \mathrm{~g}$ daging terdapat pada perlakuan pakan dengan $70 \%$ campuran ampas tahu dalam pakan. Sedangkan kadar albumin terendah yaitu $2.286 \mathrm{~g} / 100 \mathrm{~g}$ daging ikan terdapat pada perlakuan pakan tanpa ampas tahu.

\section{UCAPAN TERIMA KASIH}

Penelitian ini terlaksana atas hibah Kemenristek Dikti dalam skim penelitian dosen pemula (PDP) tahun 2016.

\section{DAFTAR PUSTAKA}

Astria J, Marsi, dan Fitrani M. 2013. Kelangsungan Hidup dan Pertumbuhan Ikan Gabus (Channa striata) Pada Berbagai Modifikasi pH Media Air Rawa Yang Diberi Substrat Tanah. Jurnal Akuakultur Rawa Indonesia. vol 1(1): 6675.

Harianti. 2013. Fekunditas dan Diameter Telur Ikan Gabus (Channa striata Bloch, 1793) di Danau Tempe, Kabupaten Wajo. Jurnal Saintek Perikanan. vol 8(2): 1824.

Isnawati NI, Sari, dan Sumarto. 2015. Pengaruh Penambahan Volume Sari Nanas Yang Berbeda Terhadap Mutu Kecap Ikan Gabus (Channa striata). JOM Bidang Perikanan dan Kelautan. vol 2(1): 1-10.

Kusumaningrum GA, Alamsjah MA, Masithah D. 2014. Uji Kadar Albumin dan Pertumbuhan Ikan Gabus (Channa striata) dengan Kadar Protein Pakan Komersial yang Berbeda. Jurnal Ilmiah Perikanan dan Kelautan. vol 6(1): 25-29.

Paiko-Aliyu M, Hasyim R, Shu-Chien AC. 2010. Influence of Dietary Lipid/Protein Ratio and Survival, Growth, Body Indices and Digestive Lipase Activity In Snakehead (Channa striatus, Bloch 1793) Fry Reared in Recirculating Water System. Aquaculture Nutrition. vol 16: 466-474.

Susilowati R, Januar HI, Fithriani D, Chasanah E. 2015. Potensi Ikan Air Tawar Budidaya Sebagai Bahan Baku Produk Nutraseutikal Berbasis Serum Albumin Ikan. JPB Kelautan dan Perikanan. vol 10(1): 37-44. 
Rahadian A, Mushawwir A, Kamil KA. 2015. Profil Albumin dan Globulin Darah Ayam Petelur Fase Layer Pada Temperatur Humidity Index yang Berbeda. Students e-journal. vol 4(1): 110.
Mushawwir A dan Latipudin D. 2011. Beberapa Parameter Biokimia Darah Ayam Ras Petelur Fase Grower dan Layer dalam Lingkungan "Upper Zonathermoneutral". Jurnal Peternakan Indonesia. vol 13(3): 191-198. 